\title{
Dynamic microhabitat shifts in space and time of caddisfly larvae (Insecta: Trichoptera) in a first-order calcareous mountain stream
}

\author{
Jan Martini ${ }^{1} \cdot$ Johann Waringer ${ }^{2}$ (D) \\ Received: 3 February 2021 / Accepted: 15 March 2021 / Published online: 19 April 2021 \\ (C) The Author(s) 2021
}

\begin{abstract}
By studying substrate (choriotope) preferences of 25 caddisfly taxa in the Schreierbach stream, a calcareous, first order tributary of the Ybbs river (Lower Austria), we aimed on (1) detecting microhabitat preferences in space and time, (2) to relate this information with ontogenetic choriotope shifts, and (3) to explore relationships between feeding guilds and choriotopes chosen. For this, we took six sets of bi-monthly multi-habitat samples of larvae at three stream sections (360 samples). Densities were highest in Drusinae juveniles (53.60 \%), Micrasema morosum (15.14\%), Drusus discolor (13.31\%) and D. monticola (4.46\%), and were significantly higher in the upper stream section $\left(1900 \pm 1039\right.$ larvae $\left.\mathrm{m}^{-2}\right)$ than in the central (205 \pm 23$)$ and lower (141 \pm 22 ). Ivlev electivity indices revealed preferences for Macrolithal in Rhyacophila spp. and Tinodes dives, for Microlithal in Drusinae juveniles, for Megalithal and Phytal in filtering Drusinae and Micrasema, and for Xylal and Akal in Limnephilinae. A cluster analysis of choriotope electivity yielded five clusters, corresponding with functional feeding types. At the instar level, the chosen grain size increased with increasing instar in some species. Observed habitat shifts in space and time reflected the interaction of instar-specific choriotope choice and longitudinal translocations.
\end{abstract}

Keywords Microhabitat shifts · Functional feeding guilds · First order mountain stream · Trichoptera larvae

\section{Introduction}

Fluvial sediments come in an amazing variety of grain sizes, ranging from clay $(0.55-1 \mu \mathrm{m})$ seeping into the streams from gold mines (Davies-Colley et al. 1992) to solid bedrock river channels where the capacity of the flow for sediment transport exceeds the sediment available within the channel (Whitbread et al. 2015). In response to this wide spectrum of grain sizes available, benthic stream invertebrates evolved a wealth of sediment relationships. Sediment dwellers, such as larvae of the caddisfly Sericostoma spp., use the sedimental interstices

Jan Martini

Jan.Martini@uibk.ac.at

Johann Waringer

johann.waringer@unvie.ac.at

1 Department of Ecology, University of Innsbruck, Technikerstrasse 25, A-6020 Innsbruck, Austria

2 Department of Functional and Evolutionary Ecology, Division Limnology, University of Vienna, Althanstrasse 14, A-1090 Vienna, Austria created by coarse gravel to a depth of $1 \mathrm{~m}$ from the surface and spend most of their life cycle there (Waringer 1987). In addition to true burrowers, however, there is always a high share of benthic taxa temporally seeking shelter and colonizing crevices within the topmost sediment layer, especially in times of high discharge where the danger of drift entry is high (Tockner and Waringer 1997). Another ecologically important aspect of mineral sediments is the fact that large particles act as stable platforms in a lotic environment, emphasizing that biological stability is closely coupled with physical stability (Gurtz and Wallace 1984). Large particles favour biofilm growth and respiration (Parker et al. 2018), and increase the biomass of water mosses (Glime and Clemons 1972; Skuja 2011) and (semi-) sessile macrozoobenthic taxa, such as Gastropda, and Hydropsychidae, Simuliidae and Elmidae larvae (Bosco and Stanford 1996; Dietrich and Waringer 1999; Scheder and Waringer 2002; Zieritz and Waringer 2008). On the other end, small sediment particles, such as sand grains, are essential as habitats for Chironomid larvae (Chaloner and Wotton 1996) or for constructing cases and shelters in Trichoptera (König and Waringer 2008; Waringer and Graf 2011; Morse et al. 2019). These examples corroborate the importance of substratum size as a prime determinant of the 
structure of lotic macroinvertebrate communities (Reice 1980; Lester et al. 1996). Integrating sampling designs were developed to cover the multitude of substrates present at a given study site. In order to break down the wide range of grain sizes covering the stream bed into more manageable structural units, the term 'choriotope' was created by Stefan (1965) which was subsequently refined by Braukmann (1987) and integrated into the AQEM method (AQEM 2002). This assessment procedure focuses on a multihabitat scheme designed for sampling choriotopes proportionally according to their presence within a sampling reach (Moog 2004; Graf et al. 2008; Ofenböck et al. 2010). In this paper, we will utilize the terms 'choriotope' and 'microhabitat' interchangeably.

In the present study, this design of Multi-Habitat-Sampling was used for providing new insights into species-specific choriotope relationships in a pristine, first order calcareous mountain brook shaped by a near-constant water temperature of $6{ }^{\circ} \mathrm{C}$. Specifically, (1) we wanted to elucidate habitat preferences of the caddisfly larvae in space and time, (2) to relate this information with ontogenetic choriotope shifts at the instar level of the most abundant species, and (3) to explore the existence of a relationship between functional feeding guilds and the choriotopes chosen.

\section{Materials and methods}

\section{Sampling and field measurements}

The spring of the Schreierbach stream $\left(47^{\circ} 45^{\prime} \mathrm{N}, 15^{\circ} 05^{\prime \prime} \mathrm{E}\right.$; $780 \mathrm{~m}$ a.s.l.) is situated on the steep eastern slope of the Großer Hetzkogel near Lunz am See, Lower Austria (Online resource 1: Fig. S1); this slope is prone to avalanches which impact riparian trees and greatly increase wooden debris import in the stream. The bed of this first order stream is a steep cascade with a slope of up to $280 \%$ discharging into the Seebach stream, which in turn is part of the catchment of the Ybbs River, a southern tributary of the Danube River. Table 1 summarizes the abiotic parameters as well as the percentage areas of mineral and biotic choriotopes present in the Schreierbach stream bed. The highest share, with respect to area percentage, takes Megalithal, overgrown by water mosses (40\% on the upper sampling site), mixed with smaller mineral grain sizes ranging from Akal to Macrolithal, and dead wood (Xylal). The Schreierbach is known for its almost constant $6{ }^{\circ} \mathrm{C}$ water temperature regime (Malicky 1978; Zwick and Zwick 2010) which was also observed during the present study (Table 1). For our study we chose three sampling stations at 174, 265 and $324 \mathrm{~m}$ spring distance, corresponding to elevations of 728, 708 and $686 \mathrm{~m}$ above sea level, respectively. Each sampling site comprised a $10 \mathrm{~m}$ stretch of streambed. Sampling took place at approximately bimonthly intervals (12 March, 19 May, 1 July, 28 August, 1 November, and 20 December, 2017). Per date and section, 20 biotic samples were taken following the standardised multi-habitat-sampling precedure (AQEM 2002). According to this standard, five mineral $($ Akal $=2-20 \mathrm{~mm}$ grain size; Microlithal $=>20-63 \mathrm{~mm}$; Mesolithal $=>63-200 \mathrm{~mm} ;$ Macrolithal $=>200-630 \mathrm{~mm}$; Megalithal $=>630 \mathrm{~mm}$ ) and two biotic choriotopes (water mosses = Phytal; submerged dead wood such as logs, roots, twigs = Xylal) were mapped at each section, and area percentages calculated (Table 1). The number of biotic samples per choriotope reflected the corresponding area percentages. Akal, Microlithal and Mesolithal were kick-sampled using a net $\left(25 \times 25 \mathrm{~cm}\right.$, effective sampling area $=625 \mathrm{~cm}^{2}$, mesh size $=$ $500 \mu \mathrm{m})$, the remaining choriotope types by removing the macrozoobenthos within a square of $625 \mathrm{~cm}^{2}$ surface area with a toothbrush. Samples were pre-sorted by brushing attached macrozoobenthos from large organic particles and mineral particles $>2 \mathrm{~cm}$, and by removing the cleaned substrate. Samples were stored in $96 \%$ ethanol and transferred to the laboratory.

At each sampling date, maximum and minimum stream width was recorded and discharge measured using a propeller-meter (Ott C2; propeller diameter $=30 \mathrm{~mm}$ ) following the principles of the velocity-area method (Dingman 1984). Physicochemical parameters (electric conductivity, $\mathrm{pH}$, oxygen concentration) were measured using electrodes (WTW Oxi 3310, WTW cond 3310, WTW pH 3310). Water temperature was recorded every $12 \mathrm{~h}$ by one data logger (HOBO Pendant Temperature/Light $8 \mathrm{~K}$ ) per stream section; unfortunately, the logger exposed within the lowest sampling section was lost in summer 2017 due to a flood event.

\section{Identification}

Caddisfly larvae were identified under a binocular microscope to the lowest taxonomical level possible using the identification key of Waringer and Graf (2011). In addition, maximum head width (to the nearest $0.01 \mathrm{~mm}$ ) for instar determination was measured in the nine most abundant taxa using an ocular micrometer. For Rhyacophila glareosa McLachlan, 1867, $R$. stigmatica Kolenati, 1859 and $R$. tristis Pictet, 1834 a reliable identification of early instars was based on the following characters: ventral teeth on anal claw present/absent; shape and coloration of head capsule. The only representatives of familiy Psychomyidae and family Brachycentridae were Tinodes dives (Pictet, 1834) and Micrasema morosum (McLachlan, 1868) respectively, therefore in this case, family characteristics could be used. Considering species Drusus monticola McLachlan, 1876, and D. discolor (Rambur, 1842) identification was based on shape and setation of head capsule and case type also. Setation patterns, metanotal sclerites, case type, and life cycle pattern were characters used for Acrophylax zerberus Brauer, 1867 and Halesus rubricollis (Pictet, 1834) identification. 
Table 1 Abiotic parameters and functional feeding guild composition of the three sampling sections in the

Schreierbach stream

\begin{tabular}{|c|c|c|c|}
\hline \multirow[t]{2}{*}{ Parameter } & \multicolumn{3}{|l|}{ Section } \\
\hline & Upper & Central & Lower \\
\hline \multicolumn{4}{|l|}{ Abiotic parameters } \\
\hline Spring distance (m) & 174 & 265 & 324 \\
\hline Elevation (m a.s.1.) & 728 & 708 & 686 \\
\hline Discharge $\left(\mathrm{m}^{3} \mathrm{~s}^{-1}\right.$; mean with range $)$ & $\begin{array}{l}0.20 \\
(0.14-0.37)\end{array}$ & $\begin{array}{l}0.12 \\
(0.11-0.18)\end{array}$ & $\begin{array}{l}0.10 \\
(0.01-0.21)\end{array}$ \\
\hline Water temperature $\left({ }^{\circ} \mathrm{C} ;\right.$ mean $\left.\pm 95 \% \mathrm{CL}\right)$ & $5.86 \pm 2.71$ & $5.96 \pm 0.44$ & - \\
\hline Conductivity $\left(\mu \mathrm{S} \mathrm{cm}^{-1} ;\right.$ mean $\left.\pm 95 \% \mathrm{CL}\right)$ & $209.2 \pm 16.3$ & $208.7 \pm 16.1$ & $208.2 \pm 16.2$ \\
\hline Oxygen saturation ( $\%$; mean $\pm 95 \% \mathrm{CL})$ & $100.9 \pm 0.34$ & $102.28 \pm 1.24$ & $102.25 \pm 1.20$ \\
\hline $\mathrm{pH}(\operatorname{mean} \pm 95 \% \mathrm{CL})$ & $8.43 \pm 0.17$ & $8.43 \pm 0.09$ & $8.47 \pm 0.20$ \\
\hline Area percentage Megalithal & 40 & 0 & 0 \\
\hline Area percentage Macrolithal & 0 & 5 & 20 \\
\hline Area percentage Mesolithal & 0 & 20 & 20 \\
\hline Area percentage Microlithal & 10 & 30 & 20 \\
\hline Area percentage Akal & 0 & 0 & 10 \\
\hline Area percentage Phytal & 25 & 30 & 25 \\
\hline Area percentage Xylal & 25 & 15 & 5 \\
\hline \multicolumn{4}{|l|}{ Functional feeding guild composition } \\
\hline Shredders $(\%)$ & 15.2 & 18.7 & 34.2 \\
\hline Grazers $(\%)$ & 64.0 & 29.0 & 29.7 \\
\hline Filtering carnivores $(\%)$ & 5.1 & 9.4 & 5.1 \\
\hline Predators $(\%)$ & 8.9 & 41.1 & 29.3 \\
\hline Collectors $(\%)$ & 6.9 & 1.8 & 1.7 \\
\hline Xylophages (\%) & 0.0 & 0.0 & 0.1 \\
\hline
\end{tabular}

\section{Statistical analyses}

Data were sorted and organised in Microsoft Excel 2010, and statistical analysis were done in R ( $R$ Core Team 2016) and STATISTICA 7.1 (@ StatSoft,Tulsa, OK 74,104, USA); in addition, PAST 4.03 (Hammer et al. 2001) was used for some PCA analyses and the PCA templates. To assess the impact of abiotic parameters in the Schreierbach stream at section and choriotope scale we used ANOVA as implemented in R package "stats" (R Core Team 2016). For evaluating Trichoptera abundance on the section scale, we log-transformed the data for a linear mixed effect model (lme, Pinheiro et al. 2017). This lme function allows using abiotic factors as fixed factors and sampling date as random factors. Moreover, the implemented corCAR function outlevels the autocorrelation effects of the repeated sampling design.

In order to obtain information on species-specific choriotope choice by the caddisfly larvae we used Ivlev's electivity index, which was originally developed for dietary preferences. Ivlev (1961) scaled his ratio in order to avoid ranges from zero to infinity present in other electivity indices. Ivlev electivity $E_{i}$ is given by
$E_{i}=\left(r_{i}-n_{i}\right) /\left(r_{i}+n_{i}\right)$

where, in our case, $r_{i}$ is the percentage of species-specific larval density on choriotope type $i$, and $n_{i}$ is the area percentage of choriotope type $i$. Ivlev electivity varies from -1 to +1 , with values between 0 and +1 indicating preference and values between 0 and -1 indicating avoidance of a given substrate. In order to refine this system, we defined a range between -0.25 and +0.25 as 'indiscriminate'.

For the settings of cluster analyses used for grouping caddisfly taxa according to species-and instar-specific Ivlev choriotope electivities, Ward's method (1963) was chosen where clusters are joined in such a way that the increase in within-group variance is minimized (minimum-variance method). As distance measure, squared Euclidian distances for normalized variables were used.

In order to explore choriotope shifts in space and time, principal component analyses for the nine most abundant caddisfly species were performed, using environmental abiotic variables and species- and choriotope-specific larval densities as data matrix. We used Scree plots of Eigen values and the Kaiser criterion (Kaiser 1960) for the identification of the 
number of significant components extracted. For the biplots, axes with the highest Eigen values were used.

\section{Results}

\section{Abiotic variables and caddisfly abundance at the three sampling sections}

Discharge in the Schreierbach stream ranged from $0.37 \mathrm{~m}^{3} \mathrm{~s}^{-1}$ during snowmelt in May at the upper stream section to $0.01 \mathrm{~m}^{3}$ $\mathrm{s}^{-1}$ in July at the lower section (Table 1). Discharge was significantly (ANOVA, $p<0.01$ ) higher in the upper than in the central and lower sampling sections, illustrating strong downwelling of surface water into the hyporheic zone along the study reach. Flow velocities (measured at $40 \%$ water depth from the bottom) were significantly different between choriotopes, and correlated with choriotope type (ANOVA, $p<0.000$ ), illustrating sediment sorting by the current: in
May, up to $0.83-1.25 \mathrm{~m} \mathrm{~s}^{-1}$ were observed on Megalithal, Macrolithal and Phytal (water mosses), 0.40-0.50 $\mathrm{m} \mathrm{s}^{-1}$ on Mesolithal and Xylal, and $0.19-0.23 \mathrm{~m} \mathrm{~s}^{-1}$ on Akal and Microlithal. With respect to physico-chemical parameters, water temperature and $\mathrm{pH}$ slightly and insignificantly increased, while conductivity insignificantly decrased downstream $\left(\mathrm{X}^{2}\right.$ tests; $\left.p>0.05\right)$. Oxygen saturation, however, significantly increased downstream ( $\mathrm{X}^{2}$ tests; $\left.p<0.001\right)$. Area percentages of choriotopes are summarized in Table 1. Megalithal was only present at the upper stream section, Akal only at the lowest section.

In total, 22 Trichoptera species were collected at the three sampling sections. The juveniles of subfamily Drusinae (Limnephilidae), of tribes Chetopterygini and Stenophylacini (Limnephilinae, Limnephilidae), and of the Rhyacophila species where larvae are fitted with tufted gills (Rhyacophila sensu stricto group) could not be identified to species level and were pooled for further analyses (Table 2). Larval densities $\left(\mathrm{n} \mathrm{m}^{-2}\right)$ were highest in Drusinae juveniles $(53.60 \%$ of the
Table 2 Trichoptera larvae in the three sections (upper, central, lower) of the Schreierbach stream, showing the taxon, mean larval densities $\left(\mathrm{n} \mathrm{m}^{-2}\right)$, based on chorioptope-specific densities on six sampling dates per section, and the percentage of total catch. Taxa are ranked in decreasing densities

\begin{tabular}{|c|c|c|c|c|}
\hline \multirow[t]{2}{*}{ Taxon } & \multicolumn{3}{|c|}{ Larval densities $\left(\mathrm{n} \mathrm{m}^{-2}\right)$} & \multirow[t]{2}{*}{ Percentage } \\
\hline & $\begin{array}{l}\text { Upper } \\
\text { section }\end{array}$ & $\begin{array}{l}\text { Central } \\
\text { section }\end{array}$ & $\begin{array}{l}\text { Lower } \\
\text { section }\end{array}$ & \\
\hline Drusinae juveniles (Limnephilidae) & 1187.96 & 11.30 & 4.28 & 53.60 \\
\hline Micrasema morosum (McLachlan, 1868) & 281.42 & 40.63 & 17.89 & 15.14 \\
\hline Drusus discolor (Rambur, 1842) & 236.63 & 45.33 & 16.92 & 13.31 \\
\hline Drusus monticola McLachlan, 1876 & 85.58 & 11.33 & 3.22 & 4.46 \\
\hline Tinodes dives (Pictet, 1834) & 26.08 & 11.33 & 3.56 & 1.83 \\
\hline Pseudopsilopteryx zimmeri (McLachlan, 1876) & 15.58 & 8.93 & 14.28 & 1.73 \\
\hline $\begin{array}{l}\text { Chaetopterygini \& Stenophylacini juveniles } \\
\text { (Limnephilidae) }\end{array}$ & 11.00 & 2.77 & 24.69 & 1.71 \\
\hline Rhyacophila glareosa McLachlan, 1867 & 12.08 & 16.83 & 4.06 & 1.47 \\
\hline Rhyacophila stigmatica Kolenati, 1859 & 7.38 & 11.23 & 11.92 & 1.36 \\
\hline Rhyacophila tristis Pictet, 1834 & 11.29 & 14.00 & 1.72 & 1.20 \\
\hline Rhyacophila s. str. juveniles & 7.00 & 5.40 & 1.50 & 0.62 \\
\hline Rhyacophila vulgaris Pictet, 1834 & 4.38 & 7.43 & 0.78 & 0.56 \\
\hline Metanoea rhaetica Schmid, 1955 & 0.00 & 1.17 & 10.17 & 0.51 \\
\hline Acrophylax zerberus Brauer, 1867 & 0.67 & 5.20 & 3.11 & 0.40 \\
\hline Chaetopterygopsis machlachlani Stein, 1974 & 1.92 & 1.07 & 6.08 & 0.40 \\
\hline Halesus rubricollis (Pictet, 1834) & 1.00 & 2.07 & 5.64 & 0.39 \\
\hline Rhyacophila aurata Brauer, 1857 & 3.92 & 4.90 & 0.00 & 0.39 \\
\hline Allogamus uncatus (Brauer, 1857) & 0.46 & 2.63 & 4.39 & 0.33 \\
\hline Lithax niger (Hagen, 1859) & 4.21 & 0.20 & 0.33 & 0.21 \\
\hline Drusus biguttatus (Pictet, 1834) & 0.25 & 0.70 & 2.58 & 0.16 \\
\hline Melampophylax melampus (McLachlan, 1876) & 0.00 & 0.67 & 1.44 & 0.09 \\
\hline Rhyacophila intermedia McLachlan, 1868 & 0.13 & 0.00 & 0.97 & 0.05 \\
\hline Chaetopteryx fusca Brauer, 1857 & 0.00 & 0.00 & 0.89 & 0.04 \\
\hline Drusus chrysotus (Rambur, 1842) & 0.46 & 0.27 & 0.00 & 0.03 \\
\hline Crunoecia kempnyi Morton, 1901 & 0.00 & 0.00 & 0.22 & 0.01 \\
\hline
\end{tabular}


total catch), in Micrasema morosum (Brachycentridae; $15.14 \%)$, Drusus discolor (13.31\%), D. monticola $(4.46 \%)$, and in Chetopterygini and Stenophylacini juveniles $(1.71 \%)$. A number of rare species were collected only in one or two stream sections: Chaetopteryx fusca Brauer, 1857and Crunoecia kempnyi Morton, 1901 in the lower section, Rhyacophila aurata Brauer, 1857, Drusus chrysotus (Rambur, 1842) in the upper and central, Metanoea rhaetica Schmid, 1955 and Melampophylax melampus (McLachlan, 1876) only in the central and lower, and Rhyacophila intermedia McLachlan, 1868 in the upper and lower section (Table 2). The remaining species were present at all three sampling sections. Trichoptera species richness (omitting pooled juveniles) did not change significantly between sampling sections and was up to 18 species at the upper, 19 at the central, and 20 at the lower section. Larval densities $( \pm$ SD) in the upper stream section were significantly higher $(1900 \pm$ 1039 larvae $\left.\mathrm{m}^{-2}\right)$ than in the central $(205 \pm 23)$ and lower stream section $(141 \pm 22 ; p<0.000$; linear mixed-effects model).

\section{Choriotopes and functional feeding guilds}

For analyzing choriotope choice (Akal, Microlithal, Mesolithal, Macrolithal, Megalithal, Phytal, Xylal) of the caddisfly community of the Schreierbach stream, we calculated mean area percentage for each choriotope type based on data given in Table 1 for the three stream sections. The latter data were combined with percentages of taxa-specific larval densities at the corresponding choriotope types, and fed in the Ivlev electivity algorithm. Table 3 summarizes Ivlev choriotope electivities of the 25 Trichoptera taxa (including juveniles which cannot be identified to species level in some groups). We noticed preferences for Macrolithal in Rhyacophila spp. (except R. glareosa) and Tinodes dives, for Microlithal in Drusinae juveniles, Lithax niger (Hagen, 1859) and Crunoecia kempnyi, for Megalithal and Phytal in filtering Drusinae and Micrasema, for Xylal in Melampophylax melampus and Chaetopteryx fusca, and for Akal in Limnephilinae. A subsequent cluster analysis (minimumvariance method; squared Euclidean distances) of the species-specific Ivlev choriotope electivities included in Table 3 revealed five clusters (Fig. 1), corresponding with functional feeding types (collectors, filtering carnivores, grazers, predators, shredders, xylophages). The dominant feeding type in cluster 1 were the predators of genus Rhyacophila and the psychomyiid Tinodes dives on Macrolithal. Cluster 2 grouped grazers, collectors and shredders with Microlithal, cluster 3 consisted of carnivorous filtering collectors and grazers on water mosses, and cluster 4 grouped shredders and predators on submerged dead wood (Xylal). Finally, the bulk of om- nivorous (shredding-predating-grazing) Limnephilinae species were summarized in cluster 5 with Akal as preferred choriotope type (Fig. 1; Table 3). The distribution patterns of species within the three stream sections mirrored the proportion of functional feeding guilds: whereas shredders were dominant in the lower section, grazers were the most abundant guild in the upper and predators in the central section (Table 1).

\section{Ontogenetic microhabitat shifts}

The instar-specific choriotope choice of the nine species of the Schreierbach caddisfly community (where juveniles could be reliably identified) was studied in detail (Fig. 2). A cluster analysis (Ward method, squared Euclidian distances) divided species into two groups (Online resource 1: Fig. S2). Group 1 consisted of species where larval densities were high on coarse substrates such as Macroand Megalithal ( $R$. stigmatica, $R$. tristis, $T$. dives, $M$. morosum, $D$. discolor), whereas in group 2 the opposite was observed (R. glareosa, D. monticola, A. zerberus, H. rubricollis); in this latter group, Akal, Micro- and Mesolithal was favoured. Within group 1, high Ivlev electivity indices for both organic (Xylal) and inorganic substrates were observed in $R$. stigmatica and, to a lesser degree, in $R$. tristis, whereas in the remaining species of this group mineral substrates alone ( $T$. dives) or mixed with Phytal were favoured (D. discolor, M. morosum). Ivlev electivity for Akal was high $(\geq 0.8)$ in A. zerberus (instars 2 and 3) and H. rubricollis (instars 4 and 5), and lower in $R$. glareosa (all instars except 2) and D. monticola (instar 5); in the latter species, instars heavily shifted between mineral grain sizes as well as between mineral and organic sediment types (Fig. 2). Moreover, in some species the chosen grain size of mineral sediments increased with increasing instar. For example, we observed negative Ivlev electivity indices for Mesolithal in instars 1 and 2 in $R$. glareosa, but increasingly positive ones from instar 3 to instar 5 (Fig. 2). Similar trends were observed in A. zerberus and M. morosum; in the latter species, electivity indices for Megalithal increased from 0.2 to 0.6 .

\section{Microhabitat shifts in time}

In order to explore patterns of choriotope shifts in time of the nine most abundant Trichoptera species in the Schreierbach, PCA analyses of substrate-specific abiotic environmental data (elevation, choriotope percentage area, substrate-specific stream velocity, conductivity, oxygen saturation, and $\mathrm{pH}$ ) were conducted (Fig. 3a). According to the Kaiser criterion, 2 factors were retained, explaining $99.9 \%$ of data variance. The PCA yielded high positive loadings for factor 1 associated 


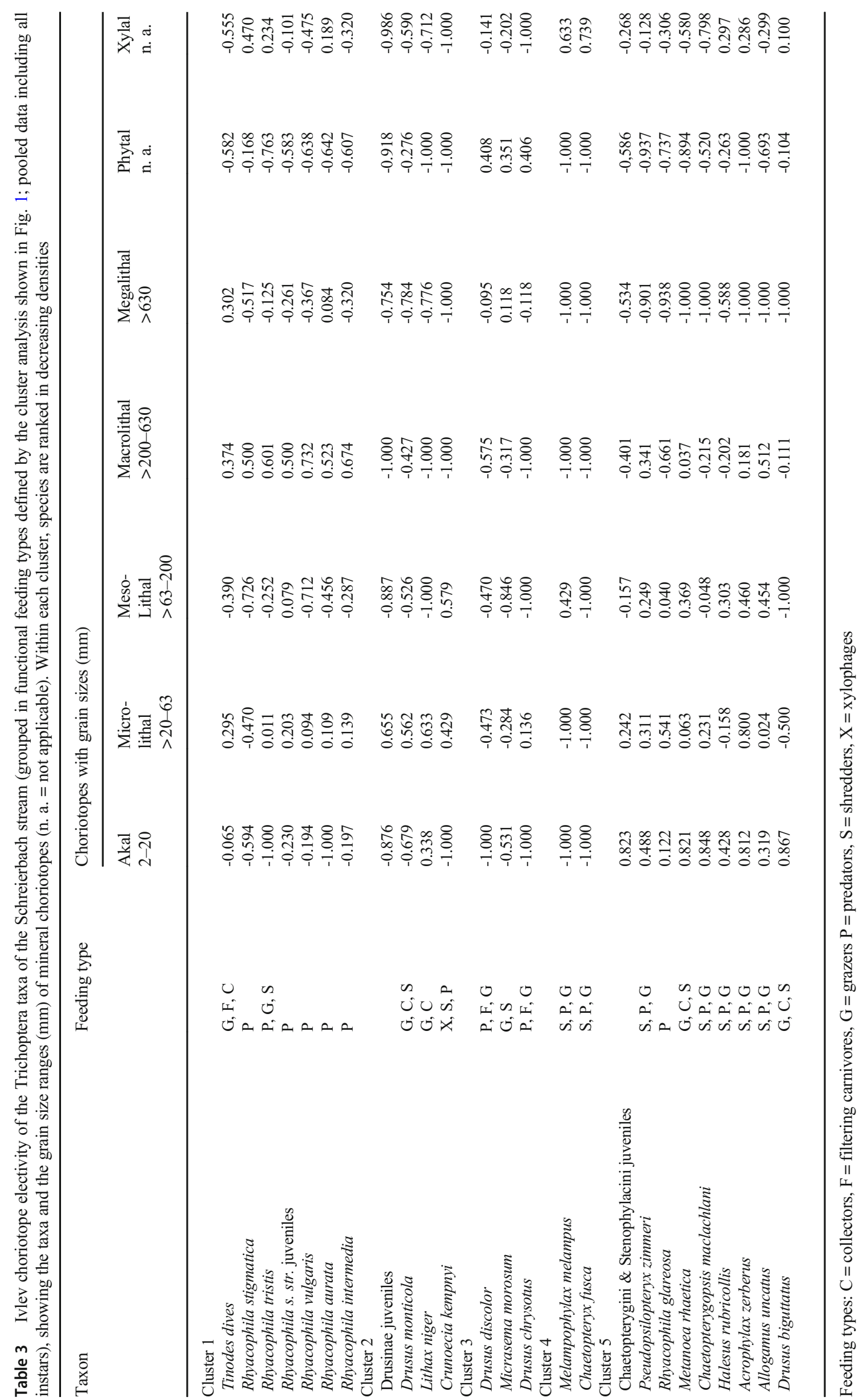




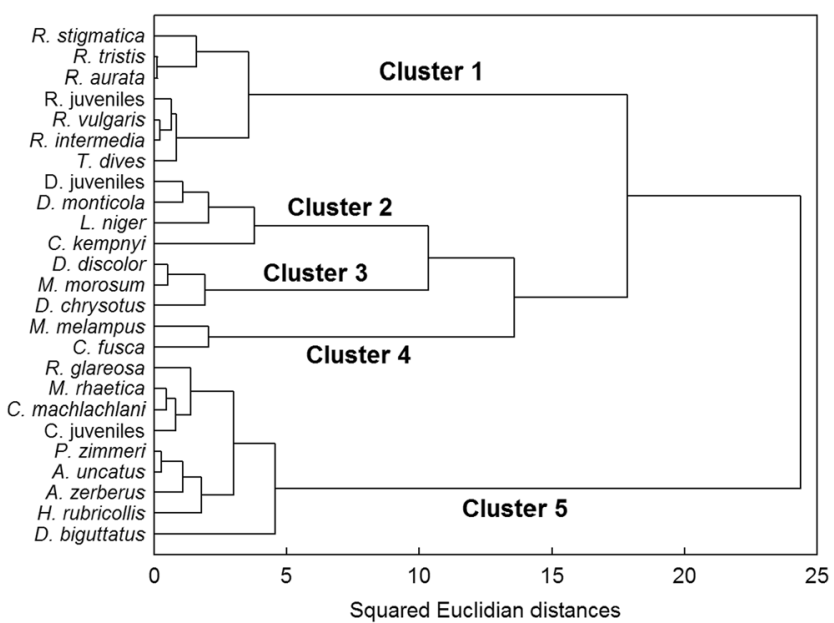

Fig. 1 Cluster diagram (minimum-variance method; squared Euclidean distances) of species-specific Ivlev choriotope electivity of 25 Trichoptera taxa in the Schreierbach stream. The five clusters numbered 1-5 define the following groups: cluster 1 - predators and Tinodes dives; cluster 2 grazers and Crunoecia kempnyi; cluster 3 - filtering carnivores and Micrasema minimum; cluster 4 - shredders; cluster 5 - shredders, grazers and Rhyacphila glareosa

with elevation and, to a lower degree, with conductivity, and low negative loadings for $\mathrm{O}_{2}$ and $\mathrm{pH}$. Therefore, this factor may be interpreted as 'elevation (x) axis' addressing the orographic situation of the three sampling stations, combined with decreasing conductivity and increasing $\mathrm{O}_{2}$ and $\mathrm{pH}$ due to increasing source distance. This axis explained $80.1 \%$ of the variance of abiotic parameters. High loadings included in factor two were correlated with area percentage of the choriotopes and, to a lesser degree, with stream velocity; therefore, this axis may be interpreted as 'choriotope (y) axis', illustrating velocity-dependent sediment sorting, accounting for $19.8 \%$ of variance.

Subsequent PCAs including species abundances observed at the six sampling dates revealed microhabitat shifts in time. In the predacious Rhyacophilidae, time-dependent intraspecific scatter within the ordination space was lowest in $R$. glareosa and higher in $R$. stigmatica and $R$. tristis (Fig. 3b). In $R$. glareosa, last instar larvae were most abundant in the central section in March (3) and May (5); with the beginning of the flight period in June (Table 4), a population shift to the upper section in July (7) was observed, consisting mostly of early instars. Subsequently, the abundance maximum of juvenile larvae again shifted from the upper section in July (7) to the downstream central section in August (8), probably caused by organismic drift. In the rest of the year, larvae of instars 2-4 remained most abundant in the central section. With respect to choriotope, the slender larvae of $R$. glareosa were most abundant in the small interstices of Microlithal on all six sampling dates (Table 3). Basically, the same dynamics in time were also observed in R. tristis. However, Microlithal was colonized in high abundance only in July and August, whereas the preferred choriotope was Macrolithal in March, May, November and December. Due to the extended autumnal flight period of R. stigmatica which lasts to the end of November at the Schreierbach, an upstream shift as detected in the former species was observed later in the year. In the PCA ordination space this is indicated by larval abundance maxima in the lower stream section from March to August (3-8), moving to the central stream section from November to December (11-12 in Fig. 3b). Macrolithal and Xylal were the preferred choriotopes of this species (Table 3).

Larvae of Micrasema morosum were most abundant in the upper Schreierbach section (Fig. 3c); however, a period of high discharge in May in the upper section greatly increased drifting of final instar larvae and caused their downstream relocation to the central section, as indicated by an abundance peak in July in the central area of the PCA biplot (Fig. 3c). In August, the abundance peak again shifted to the upper section where this peak remained also in the subsequent months. Generally, water mosses (Phytal) growing on Megalithal and less frequently, Macrolithal, were by far the most important substrate for M. morosum, illustrating the fact that large boulders (>200 mm grain size) provide stable platforms for epilithic biofilms and water moss vegetation for the scraping and shredding M. morosum, even at times of high discharge. In Tinodes dives, a grazing and filtering collector, timedependent intraspecific scatter within the ordination space was lower than in M. morosum (Fig. 3c). T. dives was most abundant in the upper stream section, the only station where Megalithal, one of the preferred choriotopes of this species, was present. Only in August (8), most larvae were sampled in the central section, mostly on Macrolithal. In May and July, many halfgrown larvae were also associated with Microlithal.

The centre of abundance for the two Drusus species was situated in the upper stream section; only in the May (5) samples of $D$. discolor, larval density was highest in the central section (Fig. 3d), possibly due to organismic drift induced by high discharge in this month which had a stronger impact on this velocityexposed filter feeder. D. discolor was most abundant on aquatic vegetation on Megalithal, D. monticola on Microlithal.

In the PCA biplots for Acrophylax zerberus and Halesus rubricollis (Fig. 3e) only five symbols are shown for each species, because, due to their synchronised life cycle, larvae were completely lacking at the sampling stations in March or August, respectively (Table 4). Highest larval densities in A. zerberus were observed on Microlithal and Akal in the central (May, July, November) and in the lower stream sections (August, December). In contrast, H. rubricollis larvae were collected mostly on Xylal, Phytal and in the smaller grain sizes of mineral choriotopes; except in November, larval abundances were highest in the lower section (Fig. 3e). 

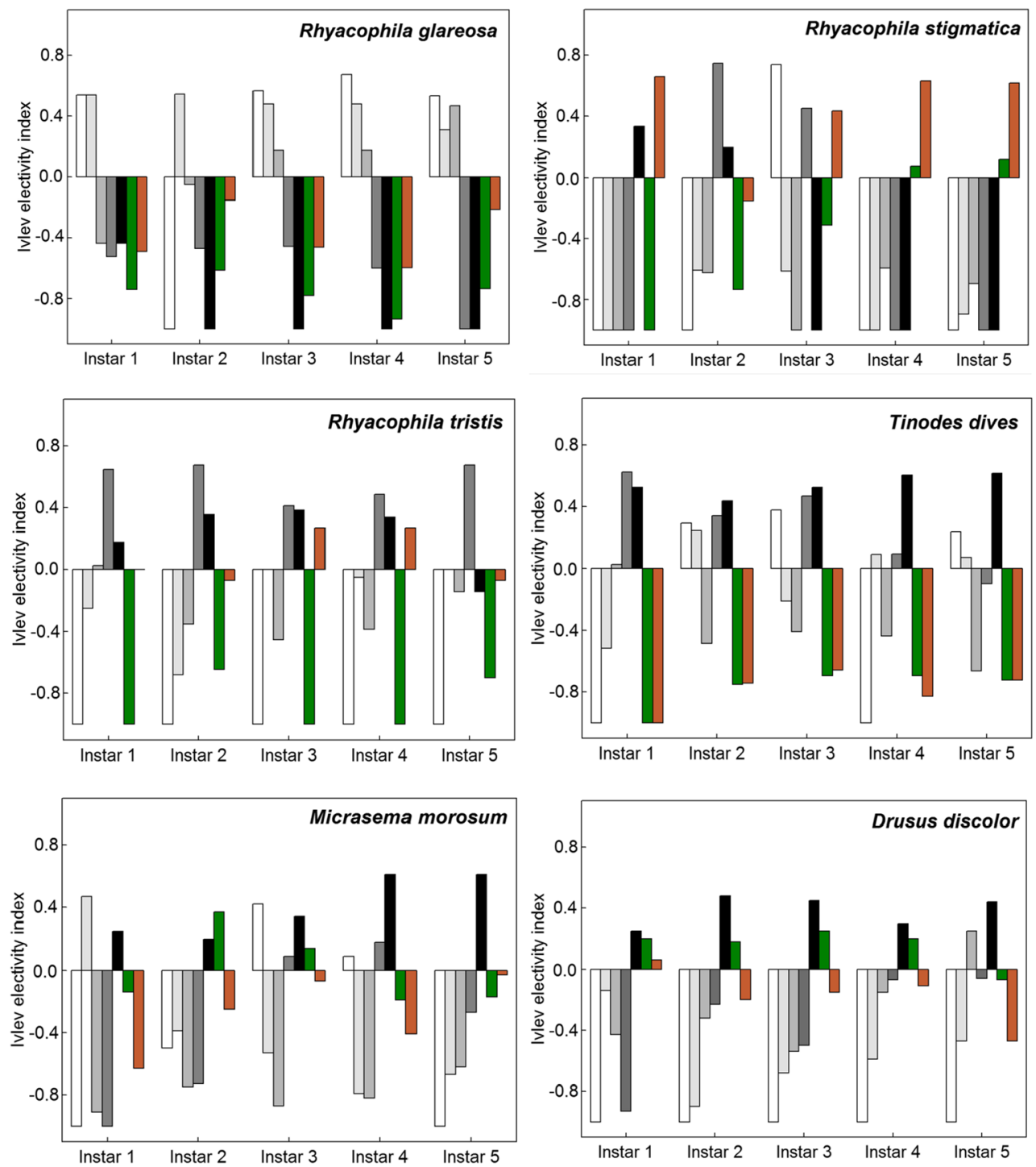

Fig. 2 Ivlev choriotope electivity of the nine most abundant Trichoptera species in the Schreierbach stream where juveniles could be separated morphologically, broken down to larval instars

\section{Discussion}

\section{Abiotic variables and caddisfly abundance at the three sampling sections}

In line with the elevation of the three sampling sites (686-728 $\mathrm{m}$ a.s.l.), snowmelt takes place in late April and May, although the increasingly warm winters with reduced snow pack in the area recently accelerate snowmelt periods significantly, thereby also impacting ecosystem metabolism in the catchment of the Ybbs (Ulseth et al. 2018). In the Schreierbach, snowmelt resulted in a significant increase in discharge up to $0.37 \mathrm{~m}^{3} \mathrm{~s}^{-1}$ on the May sampling date (upper section), whereas discharge minima of $0.01 \mathrm{~m}^{3} \mathrm{~s}^{-1}$ were observed in July (lower section). Generally, discharge in the Schreierbach is subject to strong downwelling between the upper, and the central and lower sampling sites (Table 1; Martini 2018). Downwelling sites where stream water enters the sedimental interstices play a greater role as hyporheic refugia than upwelling areas, but are more likely to dry rapidly (Dole-Olivier 2011), especially in low order reaches as the Schreierbach; this might have also caused the lower larval densities observed in the central and lower sections (Table 2). This effect is, however, at least partly compensated by the fact that intermittent sites dominated by downwelling facilitate the use of the hyporheic refugia for the biota (Stubbington et al. 2010, 2011).

With respect to physico-chemical parameters, water temperatures very slightly increased downstream due to insolation, but conductivity insignificantly decreased due to $\mathrm{CO}_{2}$ outgassing (Maas and Wicks 2017) and associated precipitation between the sampling sites situated 

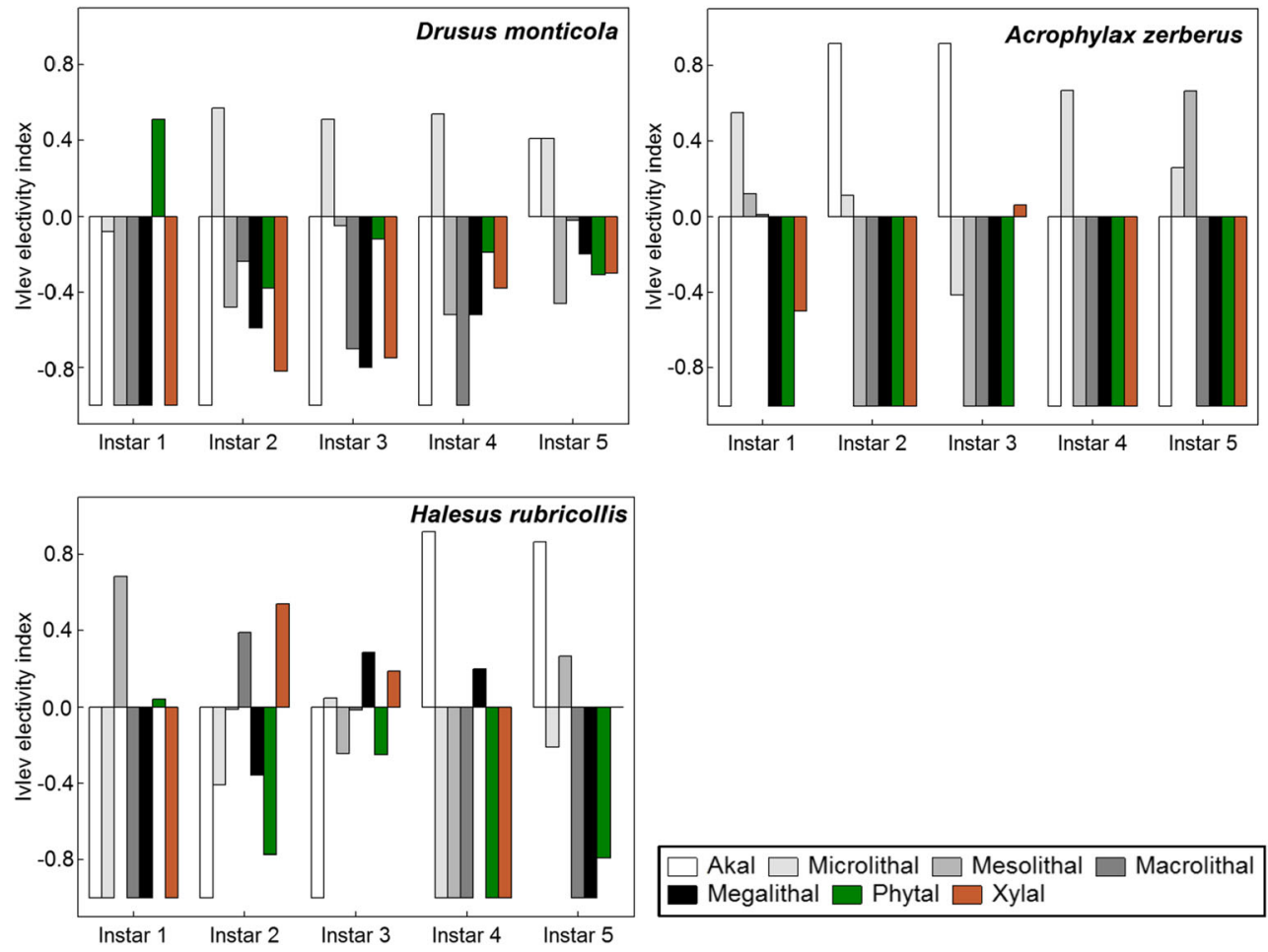

Akal $\square$ Microlithal $\square$ Mesolithal $\square$ Macrolithal
Megalithal $\square$ Phytal $\square$ Xylal

Fig. 2 (continued)

only 174 to $324 \mathrm{~m}$ downstream from the spring. Increasing primary production by epilithic biofilm and water mosses downstream of the spring area insignificantly increased $\mathrm{pH}$ from the upper to the lower sampling station. A similar, albeit significant trend $\left(\mathrm{X}^{2}\right.$ tests; $p<0.001)$ was observed in oxygen concentration: the steep cascade of the Schreierbach induced high stream velocity, which, in combination with bed roughness, increased shear at the air-water interface, and, hence, also oxygen exchange with the atmosphere (Zappa et al. 2007; Canadell et al. 2020).

Combined with the low discharge due to downwelling at the centre and lower stations, area percentages of choriotopes also affected larval densities at the three sites: when only counting taxa identified to species level (Table 2), a total of $70 \%$ of the caddisfly inventory of the Schreierbach was associated with Megalithal (Fig. 2) which was only present in the uppermost stream section investigated. Obviously, high larval densities at the upper section could be maintained throughout the year despite drift losses induced by high discharge in May, probably compensated by upstream oviposition flights of females well documented elsewhere (Gullefors 1987; Graham et al. 1997). The second choritope type mapped only at a single sampling station was Akal (lower section), the preferred substrate type of tribes Chaetopterygini and Stenophylacini of family Limnephilidae; those taxa were only rare at the Schreierbach (Table 2) and did not increase the low share of larval densities downstream.

\section{Choriotopes and functional feeding guilds}

The term 'choriotope' was created by Stefan (1965) for defining the independent structural units of the streambed. In subsequent publications, a concise system of choriotope types was established (e.g., Braukmann 1987, Moog 2004, Graf et al. 2008, Ofenböck et al. 2010) which was also the basis for the standard sampling procedure (multi-habitat sampling) used in practical assessment work initiated by the Water Framework Directive 2000/60 of the European Union. Choriotopes comprise both mineral substrates grouped according to grain size, and biotic microhabitats (AQEM 2002).

Guilds were defined by Root (1967) 'as a group of species that exploit the same class of environmental resources in a similar way' (cited in the seminal paper of Simberloff and Dayan 1991). The term quickly became a cornerstone in community ecology and has also been consistently used in more specific contexts in limnological research, ranging from reproductive fish guilds (Balon 1975) and fish environmental guilds (Welcomme et al. 2005) to the concept of macroinvertebrate functional feeding groups in the River Continuum Concept. For the latter, the unifying principle is a functional analogy and, therefore, similar resource usage mode, of mouthparts covering a wide range of phylogenetic origins (Vannote et al. 1980). In the Trichoptera larvae of the Schreierbach, carnivorous filterers ( $F$ in Table 3 ) are fitted with toothed mandible edges combined with additional filtering spines on legs and the first abdominal sternum, well suited 


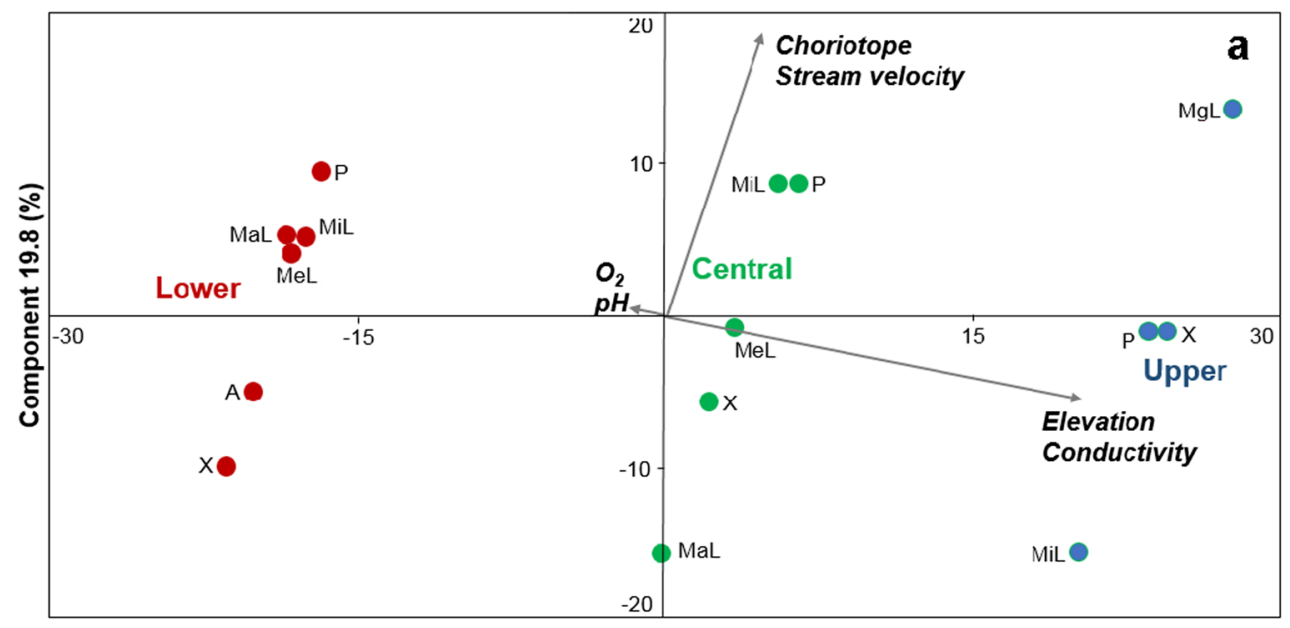

Component $1(80.1 \%)$

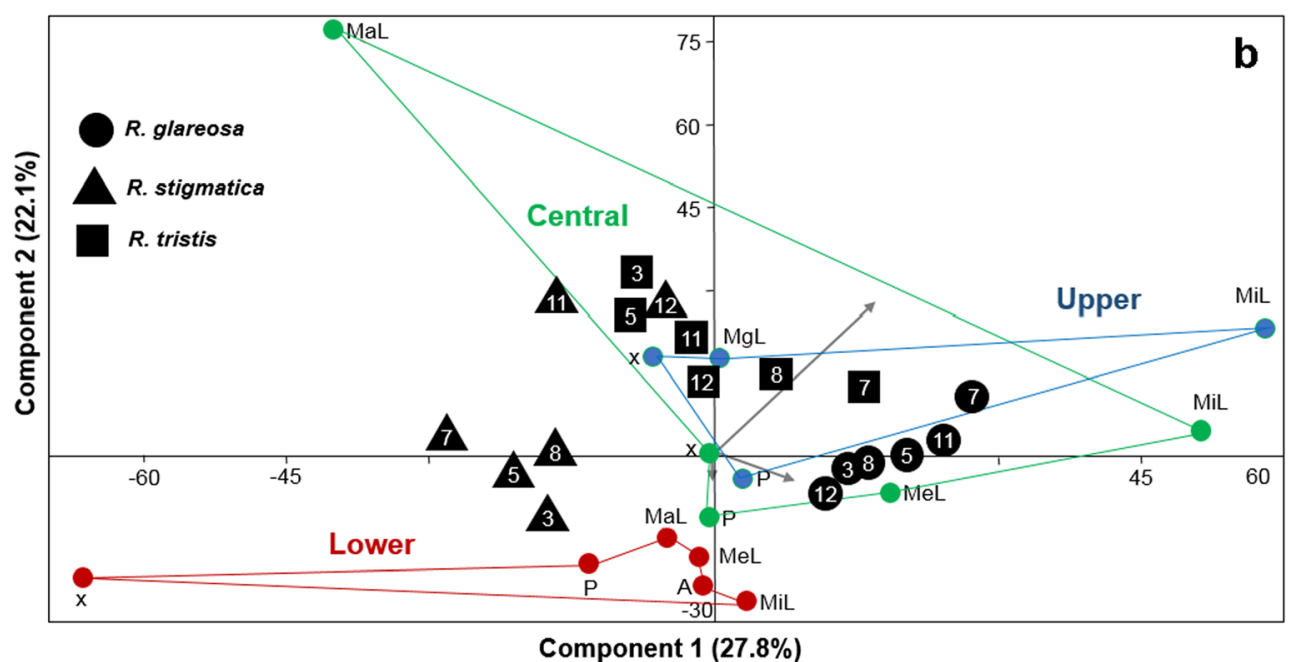

Fig. 3 a PCA analyses of substrate-specific abiotic environmental data. b-e PCA biplots illustrating choriotope shifts in time of the nine most abundant Trichoptera species in the Schreierbach stream. Axis legends include variances explained (\%) by component axes 1 and 2 . Upper, central and lower sampling sections are colour-coded, with each choritope type represented by a dot (A - Akal, MaL - Macrolithal, MeL

for filtering drifting prey. Omnivorous shredders (S), feeding on aquatic vegetation and coarse particulate organic matter (CPOM), evolved toothed mandibles, but lack additional spines and filtering bristles. Epilithic grazers $(\mathrm{G})$ use epilithic algal mats and biofilm growing on the surface of large mineral particles; they developed spoon-shaped mandibles without teeth for scraping (Vitecek et al. 2015), but also, to a lesser degree, for collecting fine particulate organic matter $(\mathrm{C}$, FPOM). In predators (P), e.g. Rhyacophila spp., mandibles are fitted with apical teeth and are frequently slightly asymmetrical: the right mandible has a short, stout basal tooth, lacking on the left mandible and replaced there by a straight cutting edge for grabbing and crushing the prey (Waringer and Malicky 2019). Xylophage mouthparts (X) resemble shredder mandibles, but are especially stout, with terminal teeth and
- Mesolithal, MiL - Microlithal, MgL - Megalithal, P - Phytal, X - Xylal). Environmental gradients are indicated by grey arrows (longest arrow elevation + conductivity, intermediate arrow - stream velocity, shortest arrow - ph + oxygen concentration), sampling dates are inscribed within larval abundance symbols (3 - 12 March, 5 - 19 May, 7-1 July, 8 - 28 August, $11-1$ November, 12 - 20 December)

strong cutting edges for handling wood and root particles colonized by fungi and bacteria (Graf et al. 2008).

In a lotic environment, primary consumers belonging to the grazer guild heavily rely on sediment grain sizes large enough to remain stable also midstream where the biomass of epilithic algae is highest (König and Waringer 2008). In the Schreierbach, this fully applied to the vagile grazers of cluster group 2 (Fig. 1) associated with grain sizes $>20 \mathrm{~mm}$, and even more so in the semi-sessile $T$. dives on Megalithal. The latter species strongly needs large, stable platforms for its fixed silk galleries. Shredders either used coarse particulate organic matter trapped in fine sediments (Akal) as shown in cluster group 5 , submerged dead wood (cluster group 4), or aquatic macrophytes (water mosses) attached to coarse mineral substrate, as shown in M. morosum (Table 3). Generally, the biomass of 


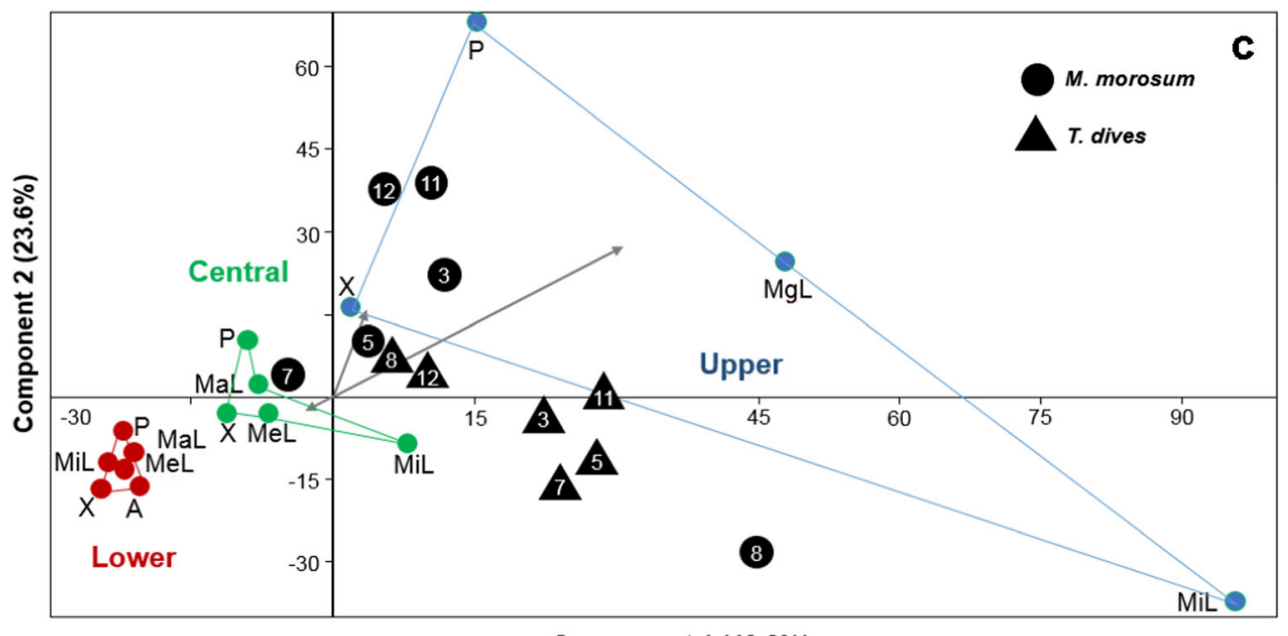

Component 1 (43.6\%)

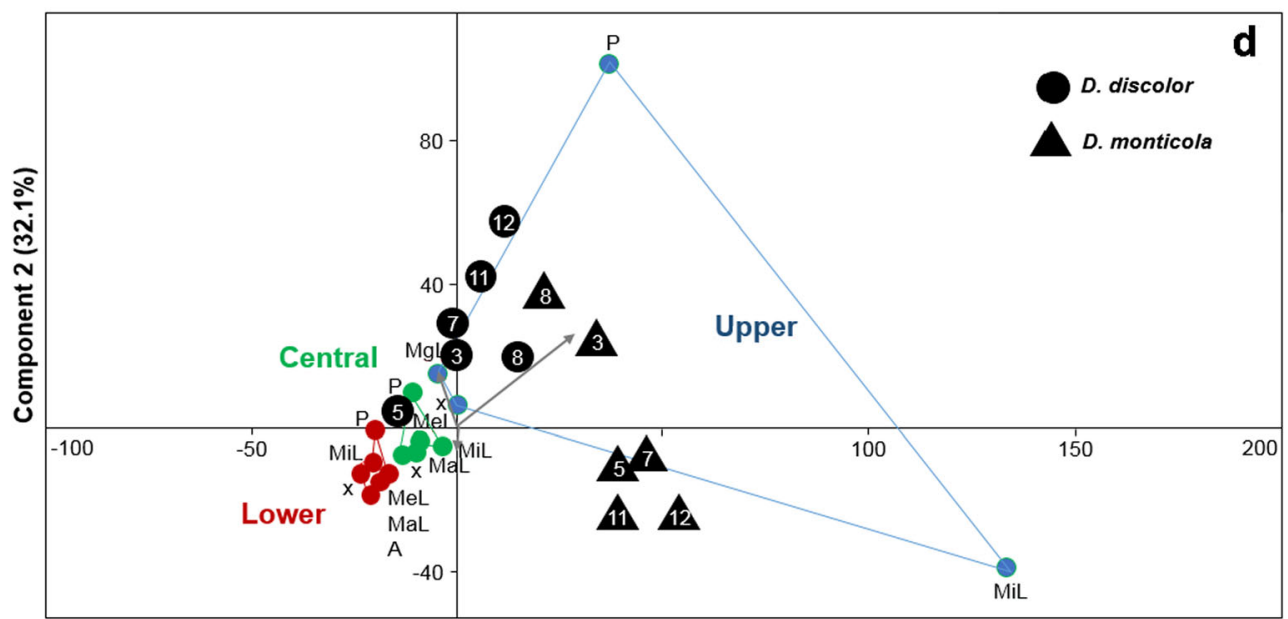

Component 1 (52.8\%)

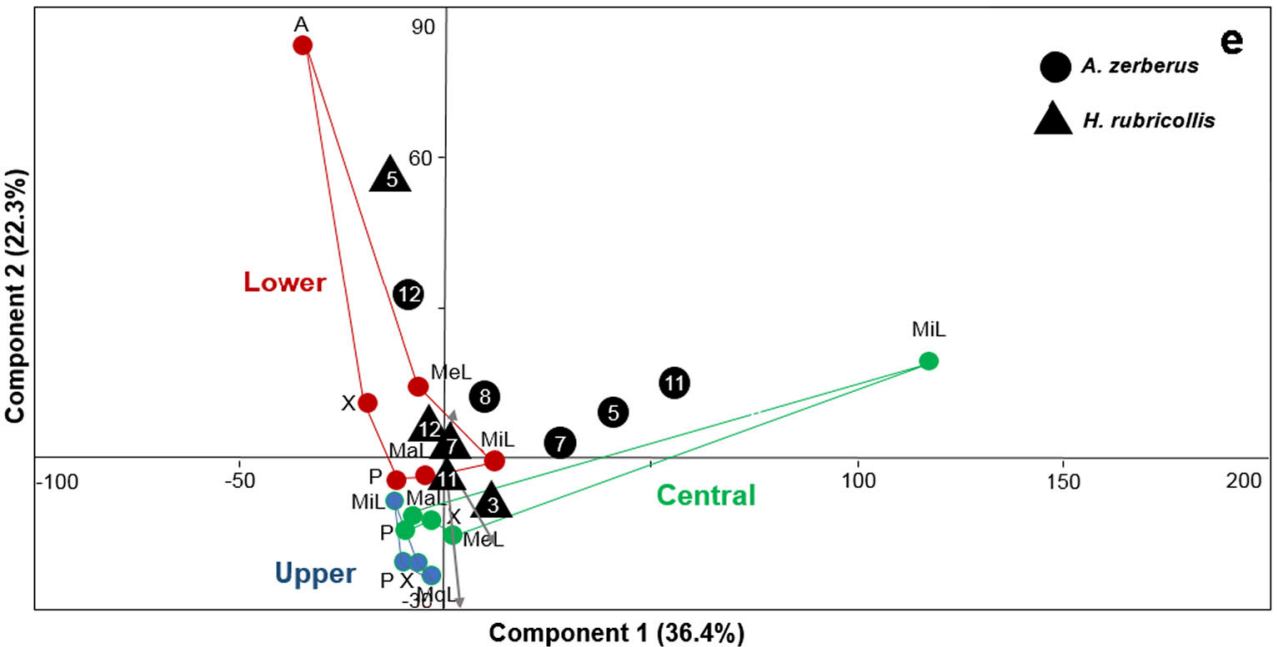

Fig. 3 (continued)

aquatic mosses peaks on current-exposed bedrock and large, stable cobbles and boulders (Glime and Clemons 1972; Skuja
2011). The latter choriotope has been also associated with the two Drusinae filtering carnivores of cluster group 3; in fact, 
Table 4 Life history data of the nine most abundant Trichoptera species in the Schreierbach stream where early instars could be separated morphologically; showing the species, the percentages of larval instars
(\% instar $1 / 2 / 3 / 4 / 5$ ) observed on the six sampling dates (maximum percentages per date in bold), and the flight periods

\begin{tabular}{|c|c|c|c|c|c|c|c|}
\hline Species & $12 \mathrm{Mar}$ & 19 May & $1 \mathrm{Jul}$ & 28 Aug & $1 \mathrm{Nov}$ & $20 \mathrm{Dec}$ & Flight period \\
\hline Rhyacophila glareosa & $4 / 16 / 34 / 7 / 39$ & $16 / 12 / 27 / 8 / 37$ & $\mathbf{6 8} / 0 / 14 / 18 / 0$ & $17 / 32 / 8 / \mathbf{4 3} / 0$ & $3 / 36 / 6 / 43 / 12$ & $0 / 23 / 29 / 4 / 44$ & Jun - Sep \\
\hline Rhyacophila stigmatica & $0 / 4 / 10 / 23 / 63$ & $0 / 0 / 0 / 50 / \mathbf{5 0}$ & $20 / \mathbf{4 5} / 20 / 7 / 8$ & $0 / \mathbf{3 5} / 28 / 26 / 11$ & $1 / 67 / 3 / 13 / 16$ & $0 / 86 / 2 / 10 / 2$ & Jun - Nov \\
\hline Rhyacophila tristis & $0 / 6 / 2 / 23 / 69$ & $13 / 44 / 25 / 4 / 14$ & $0 / 0 / 38 / \mathbf{5 6} / 6$ & $37 / 2 / 15 / 46 / 0$ & $25 / 44 / 19 / 4 / 8$ & $28 / 47 / 1 / 1 / 23$ & May - Sep \\
\hline Tinodes dives & $2 / 11 / 22 / 11 / 54$ & $0 / 26 / 18 / 43 / 13$ & $0 / 27 / 58 / 15 / 0$ & $3 / 0 / 80 / 6 / 11$ & $3 / \mathbf{5 1} / 19 / 14 / 13$ & $9 / 22 / 42 / 2 / 25$ & Jun - Sep \\
\hline Micrasema morosum & $0 / 11 / 14 / 39 / 36$ & $8 / 11 / 19 / 15 / 47$ & $16 / 8 / 22 / 18 / 36$ & $67 / 9 / 9 / 11 / 3$ & $18 / 66 / 7 / 6 / 3$ & $7 / 38 / \mathbf{3 9} / 11 / 5$ & May - Jul \\
\hline Drusus discolor & $2 / 24 / 33 / 23 / 18$ & $0 / 8 / 25 / \mathbf{3 4} / 33$ & $1 / 10 / 31 / 33 / 25$ & $81 / 2 / 8 / 7 / 2$ & $42 / 39 / 7 / 9 / 3$ & $19 / 46 / 12 / 17 / 6$ & Jun - Sep \\
\hline Drusus monticola & $1 / 27 / 20 / \mathbf{5 0} / 2$ & $0 / 23 / 34 / 0 / 43$ & $0 / 0 / 11 / 0 / 89$ & $6 / 76 / 4 / 0 / 14$ & $0 / \mathbf{8 8} / 9 / 0 / 3$ & $0 / \mathbf{9 2} / 7 / 0 / 1$ & Mar - Jul \\
\hline Acrophylax zerberus & $0 / 0 / 0 / 0 / 0$ & $100 / 0 / 0 / 0 / 0$ & $100 / 0 / 0 / 0 / 0$ & 0/0/0/0/100 & $0 / 0 / 0 / 0 / 100$ & $0 / 14 / 86 / 0 / 0$ & Mar - Jul \\
\hline Halesus rubricollis & $0 / 8 / \mathbf{5 7} / 8 / 27$ & $0 / 0 / 0 / 29 / 71$ & $0 / 0 / 0 / 0 / 100$ & $0 / 0 / 0 / 0 / 0$ & $\mathbf{9 4} / 6 / 0 / 0 / 0$ & $6 / \mathbf{5 9} / 35 / 0 / 0$ & Jul - Sep \\
\hline
\end{tabular}

Drusus larvae are able to withstand stream velocities up to $0.93 \mathrm{~m} \mathrm{~s}^{-1}$ where they still keep filtering for prey (Waringer et al. 2020). The predators included in cluster group 1 (Rhyacophila spp.) were mostly associated with Macro- and Megalithal which is in line with the findings of Graf et al. (2008) and Wallace (1990). In fact, the Rhyacophila species are vagile predators; due to their slim head capsule and body, they are able to effectively track their prey in the large pore spaces of their favoured Macro- and Megalithal choriotopes (Waringer and Graf 2011). However, due to the fact that they can withstand flow velocities up to $2 \mathrm{~m} \mathrm{~s}^{-1}$, they are also able to prey at the exposed upper surface of coarse substrates where they can secure themselves by a silken thread in order to prevent drifting (Graf 2012).

\section{Ontogenetic microhabitat shifts}

Group 1 of the cluster analysis consisted of species associated with coarse substrates (Macro- and Megalithal). From this group, the two predacious Rhyacophila species $R$. stigmatica and $R$. tristis are known to search their prey in the interstices and crevices of mineralic substrates (Martin and Mackay 1983; Waringer and Graf 2011; Taira and Tanida 2013). The next member of group 1, Micrasema morosum, is a scraper feeding on epilithic epiphyton (Malicky 1973; Becker 1994) and incorporates thin plant fragments in its predominantely silken case (Vieria-Lanero et al. 1998, Waringer and Graf 2011). In fast-flowing torrents such as the Schreierbach, periphyton, biofilm and water mosses are mostly attached to large mineral particles able to withstand the current and thereby preventing the mechanical removal of periphyton which very often occurs in small particle sizes being part of moving bedload. Stable platforms as microhabitats are also important for $T$. dives and $D$. discolor. The former species attaches its long, sinuous silken galleries to stable rocks. The larvae dwell in those structures and feed on periphyton from the surrounding substrate; however, the galleries are also used for filtering algae and cultivating diatoms (Hasselrot 1993). Drusus discolor, as a carnivorous filter feeder, lives in aquatic mosses exposed to high current; the woolly hair cover on its head capsule and pronotum mimics a colonisable habitat and attracts additional primary consumers as prey which are grabbed and consumed by the Drusus larva (Bohle 1983).

In group 2 of the cluster anlysis ( $R$. glareosa, D. monticola, A. zerberus, $H$. rubricollis) choriotopes of smaller grain sizes (Akal, Micro- and Mesolithal) were favoured. This may reflect the fact that the transportable cases in D. monticola and A. zerberus consist of small sand grains in the millimetre (Akal) range. The typical smooth cases of $H$. rubricollis, on the other hand, are composed of detrital and small leaf fragments; such material is frequently accumulated and mixed with sand grains. The reason why $R$. glareosa has been separated by the cluster analysis can be possibly explained by the favourable length/width ratio of the head capsule in this species which enables the larvae to also use the more restricted interstices in smaller grain sizes.

No or only stochastic ontogenetic choriotope shifts were observed in $R$. stigmatica, $R$. tristis, $T$. dives, $D$. discolor, D. monticola and H. rubricollis. In R. glareosa, A. zerberus and M. morosum, however, the grain size of the preferred mineral choriotopes increased during ontogeny (Fig. 2). This reflects the fact that an increasing body size of $R$. glareosa larvae also required larger interstitial crevices which were only present in coarser sediments. In addition, due to hydraulic sediment sorting processes, sediment grain size is significantly and positively correlated with stream velocity. For species on the sediment surface (M. morosum, A. zerberus), increasing positive electivity indices of older larvae for coarse grain sizes also reflect an exposition to higher hydraulic stress. In final larval instars, increased adhesive friction due to their higher submerged weight and improved strength simply enables them to expand the colonizable space on the sediment surface to high velocity patches on the stream bed (Waringer et al. 2020). For 
example, in the Limnephilid caddisfly Allogamus auricollis, larvae with heads directed towards the water flow, the current speed necessary to dislodge the larvae were $0.13 \mathrm{~ms}^{-1}$ in first instars but $0.28 \mathrm{~ms}^{-1}$ in fifth instars (Waringer 1989).

\section{Microhabitat shifts in time}

The observed scatter of time-coded species symbols within the PCA ordination spaces (Fig. 3b-e) reflects temporal shifts between the three stream sections investigated, and the choriotope types colonized by the larvae. For lotic taxa without aerial phases, Humphries and Ruxton (2002) demonstrated that small-scale movements along the streambed infer upstream shifts, thereby compensating drift losses. In stream insects with aerial phases, however, upstream shifts between stream sections may be driven by migrating females flying for oviposition. In fact, upstream oviposition flights of stoneflies (Leuctra spp., Nemoura spp., Isoperla spp., Siphonoperla spp.) are well documented, based on evidence that oviposition took place upstream from emergence areas in high concentrations (Zwick 1990). In Trichoptera, migration flights of females carrying eggs were also observed (Graham et al. 1997), and the data provided by Gullefors (1987) clearly support the hypothesis of the colonization cycle suggesting that egg-bearing caddisfly females are mainly moving in an upstream direction. Such observations are in line with our data from the Schreierbach where in the three Rhyacophila species and in Micrasema morosum the maximum of larval densities, consisting mostly of early instars, shifted upstream with the beginning of the flight period, most probably initiated by oviposition of upstream-migrating females. This can be clearly seen when comparing, e.g., the positions of the circular M. morosum labels inscribed 5 to 7 with label 8 in Fig. 3c. In addition to upstream shifts, relocations downstream were also frequently observed in the PCA analyses. For example, Drusus discolor was most abundant in the upper Schreierbach section throughout the year except in May when larval density was highest in the central section (Fig. 3d). The driving force of this relocation is organismic drift, even more so during periods of high discharge, as experienced in May in the Schreierbach. Organismic drift is an inherent phenomenon in streams and rivers, and one of the best-studied topics in stream ecology (e.g., Statzner et al. 1987; Brittain and Eikeland 1988; Waringer 1992; Anholt 1995; Barbero et al. 2013). As a typical carnivorous filtering species exposed to high stream velocities, $D$. discolor is prone to drift entry. In a recent study on hydraulic niche utilization by larvae of the three Drusinae clades (Waringer et al. 2020) it could be shown that the filtering carnivore clade, to which $D$. discolor belongs, experienced significantly higher hydraulic drag in the field (up to $1700 * 10^{-6} \mathrm{~N}$ ) than the other clades, with only $25 \%$ of drag force compensated by adhesive friction based on submerged weight.
Generally, biomass shifts induced by organismic drift tend to be high; in a drift study conducted in the adjoining catchment of the Schreierbach (Lunzer Seebach) total drift rates through a cross-section of the brook were up to 1,188.000 specimens per day (Waringer 1992).

Of course, scatter of time-coded species symbols within the PCA ordination spaces are also due to the choriotope types colonized by different species and larval instars (e.g., Braukmann 1987; Janecek et al. 1991; Graf et al. 2008). Choriotopes are the basis for the multi-habitat sampling procedure which provides one of the standard tools for ecological assessments in the framework of the European Water Framework Directive (AQEM 2002). In the Schreierbach, choriotope choice between taxa ranged widely. For example, in Micrasema morosum, a species significantly associated with coarse mineralic sediments, Megalithal and Xylal were the preferred substrates in the upper section in March and May, replaced by Macrolithal in July, the coarsest substrate available for drifting larvae in the central section. After oviposition, first instar larvae were most abundant in Microlithal substrate, whereas second and third instars were also frequently sampled in phytal (Fig. 3c). These findings reflect the fact that early instar larvae of the species studied in detail generally were most abundant in the smallest grain sizes of mineral sediments available, simply because the small interstices match the body size of those juveniles. The latter, however, may also apply to the full spectrum of instars. For example, the slender larvae of $R$. glareosa were most abundant in the small interstices of Microlithal on all six sampling sites due to the favourable length/width ratio of their head capsule of 1.61 which is distinctly higher than in $R$. stigmatica (1.28) and $R$. tristis (1.49) which favoured coarser sediment types. Combined with their slender body, $R$. glareosa larvae of all size classes are well adapted to such space-restricted habitats. Microlithal exposed to low velocities were also favoured by the grazing-collecting shredder D. biguttatus. On the other hand, the filtering larvae of $D$. discolor were mostly collected within water mosses on the upper surface of stable Megalithal exposed to high flow velocities which matches the observations of Kalaninová et al. (2014) who observed this species mainly on boulder banks. This habitat choice is illustrated in Fig. 3d where the orientation of the symbols for both Drusus species are situated in opposite directions of the grey velocity vector.

Supplementary Information The online version contains supplementary material available at https://doi.org/10.1007/s11756-021-00741-w.

Funding Open access funding provided by University of Vienna.

\section{Declarations}

Conflict of interest On behalf of all authors, the corresponding author states that there is no conflict of interest. 
Open Access This article is licensed under a Creative Commons Attribution 4.0 International License, which permits use, sharing, adaptation, distribution and reproduction in any medium or format, as long as you give appropriate credit to the original author(s) and the source, provide a link to the Creative Commons licence, and indicate if changes were made. The images or other third party material in this article are included in the article's Creative Commons licence, unless indicated otherwise in a credit line to the material. If material is not included in the article's Creative Commons licence and your intended use is not permitted by statutory regulation or exceeds the permitted use, you will need to obtain permission directly from the copyright holder. To view a copy of this licence, visit http://creativecommons.org/licenses/by/4.0/.

\section{References}

Anholt BR (1995) Density dependence resolves the stream drift paradox. Ecology 76:2235-2239. https://doi.org/10.2307/1941697

AQEM (2002) Manual for the application of the AQEM method. A comprehensive method to assess European streams using benthic macroinvertebrates, developed for the purpose of the Water Framework Directive. Version 1.0, February 2002, pp 1-89

Balon EK (1975) Reproductive guilds of fishes: a proposal and definition. J Fish Res Board Canada 32:821-864. https://doi.org/10.1139/f75110

Barbero MD, Oberto AM, Gualdoni CM (2013) Spatial and temporal patterns of macroinvertebrates in drift and on substrate of a mountain stream (Cordoba, Central Argentina). Acta Limnol Bras 25: 375-386. https://doi.org/10.1590/S2179-975X2013000400003

Becker G (1994) Food preference by five trichopteran scrapers. Hydrobiologia 273:171-178. https://doi.org/10.1007/BF00005640

Bohle HW (1983) Driftfang und Nahrungserwerb der Larven von Drusus discolor (Trichoptera, Limnephilidae). Arch Hydrobiol 97:455-470

Bosco IJ, Stanford JA (1996) An ecological study of a regulated prairie stream in western Montana. Reg Rivers 12:597-615 https://doi.org/ 10.1002/(SICI)1099-1646(199611)12:6<597::AID-RRR417>3.0. $\mathrm{CO} ; 2-\mathrm{R}$

Braukmann U (1987) Zoozönologische und saprobiologische Beiträge zu einer allgemeinen regionalen Bachtypologie. Arch Hydrobiol. Beih Ergeb Limnol 26:1-355. https://doi.org/10.1002/iroh.19890740113

Brittain JE, Eikeland TJ (1988) Invertebrate drift - A review. Hydrobiologia 166:77-93. https://doi.org/10.1007/BF00017485

Canadell MB, Gómez-Gener L, Clémencon M, Lane SN, Battin TJ (2020) Daily entropy of dissolved oxygen reveals different energetic regimes and drivers among high-mountain stream types. Limnol Oceanogr 9999:1-17. https://doi.org/10.1002/lno.11670

Chaloner DT, Wotton RS (1996) Substratum preferences by larvae of three species of midge (Diptera: Chironomidae). Hydrobiologia 339:93-99

Davies-Colley RJ, Hickey CW, Quinn JM, Ryan PA (1992) Effects of clay discharges on streams. 1. Optical properties and epilithon. Hydrobiologia 248:215-234. https://doi.org/10.1007/BF00006150

Dietrich F, Waringer J (1999) Distribution patterns and habitat characterization of Elmidae and Hydraenidae (Insecta: Coleoptera) in the Weidlingbach near Vienna, Austria. Int Rev Hydrobiol 84:1-15. https://doi.org/10.1002/iroh.199900001

Dingman SL (1984) Fluvial Hydrology. Freeman and Company, New York

Dole-Olivier MJ (2011) The hyporheic refuge hypothesis reconsidered: a review of hydrological aspects. Mar Freshwat Res 62:1281-1302. https://doi.org/10.1071/MF11084

Glime JM, Clemons RM (1972) Species diversity of stream insects of Fontinalis spp. compared to diversity on artificial substrates. Ecology 53:458-464
Graf W (2012) Rhyacophila fasciata Hagen, 1859 - eine Köcherfliege als Insekt des Jahres 2013. Beitr Entomofaun 13:133-141

Graf W, Murphy J, Dahl J, Zamora-Muñoz C, López-Rodríguez MJ (2008) Trichoptera. In: Schmidt-Kloiber A, Hering D (eds) Distribution and ecological preferences of European freshwater organisms, vol 1. Pensoft Publishers, Sofia

Graham SE, Storey R, Smith B (1997) Dispersal distances of aquatic insects: upstream crawling by benthic EPT larvae and flight of adult Trichoptera along valley floors. New Zeal J Mar Fresh Res 51:146164. https://doi.org/10.1080/00288330.2016.1268175

Gullefors B (1987) Changes in flight direction of caddisflies when meeting changes in the environment. In: Bournaud M, Tachet $\mathrm{H}$ (eds) Proceedings of the Fifth International Symposium on Trichoptera. Series Entomologica, vol 39. Springer, Dordrecht, pp 229-233

Gurtz B, Wallace M (1984) Substrate-mediated response of streaminvertebrates to disturbance. Ecology 65:1556-1567. https://doi. org $/ 10.2307 / 1939135$

Hammer Ø, Harper DAT, Ryan PD (2001) PAST: Paleontological Statistics software package for education and data analysis. Palaeontol Electron 4:1-9

Hasselrot AT (1993) The reason for doodle shaping of galleries in Tinodes waeneri (L.) larvae. In: Otto C (ed) Proceedings of the Seventh International Symposium on Trichoptera. Backhuys Publishers, Kerkwerve, pp 267-271

Humphries S, Ruxton GD (2002) Is there really a drift paradox? J Anim Ecol 71:151-154. https://doi.org/10.1046/j.0021-8790.2001.00579. $\mathrm{x}$

Ivlev VS (1961) Experimental ecology of the feeding of fishes. Yale University Press, New Haven

Janecek BFU, Grasser U, Moog O (1991) Choriotope-specific macrozoobenthic assemblages of the Weißach, a Bavarian mountain stream (Germany). In: Proceedings of the fourth European Congress of Entomology, XIII. SIECC, Hungarian Natural History Museum, Budapest, pp 487-495

Kaiser HF (1960) The application of electronic computers to factor analysis. Educ Psychol Measur 20:141-151

Kalaninová D, Bulánková E, Šporka F (2014) Caddisflies (Trichoptera) as good indicators of environmental stress in mountain lotic ecosystems. Biologia 69:1030-1045. https://doi.org/10.2478/s11756-0140405-5

König E, Waringer J (2008) The ballast stones in Silo nigricornis cases (Insecta: Trichoptera): drift resistance and ecological benefits, investigated by acoustic Doppler velocimetry. Large Rivers 18:311-328. https://doi.org/10.1127/lr/18/2008/311

Lester RJ, Mitchell SE, Scott D (1996) Substrate and shade: Mechanisms of willow tree influence on the macroinvertebrate community of Heeney Creek, South Island,New Zealand. Arch Hydrobiol 136: $145-158$

Maas BJ, Wicks CM (2017) $\mathrm{CO}_{2}$ outgassing from spring waters. Aquat Geochem 23:53-60

Malicky H (1973) Trichoptera (Köcherfliegen). In: Helmcke JG, Starck D, Wermuth H (eds) Handbuch der Zoologie. IV. Band: Arthropoda, 2. Hälfte: Insecta. Zweite Auflage. 2.Teil: Spezielles: 29. De Gruyter, Berlin, pp 1-114

Malicky H (1978) Der Temperaturgang einiger niederösterreichischer Gebirgsbäche. Wetter Leben 30:170-183

Martin ID, Mackay RJ (1983) Growth rates and prey selection of two congeneric predatory caddisflies (Trichoptera: Rhyacophilidae). Can J Zool 61:895-900. https://doi.org/10.1139/Z83-117

Martini J (2018) Diversity, microhabitat distribution and life cycles of Trichoptera in the Schreierbach (Lunz, Lower Austria). Master Thesis, University of Vienna, Vienna

Moog O (2004) Standardisierung der habitatanteilig gewichteten Makrozoobenthos-Aufsammlung in Fließgewässern (MultiHabitat-Sampling; MHS). Bundesministerium für Land- und Forstwirtschaft, Umwelt und Wasserwirtschaft, Wien 
Morse JC, Frandsen PB, Graf W, Thomas JA (2019) Diversity and ecosystem services of Trichoptera. Insects 10(5):125. https://doi.org/10. 3390/insects 10050125

Ofenböck T, Moog O, Hartmann A, Stubauer I (2010) Leitfaden zur Erhebung der biologischen Qualitätselemente. Teil A2 Makrozoobenthos. Bundesministerium für Land- und Forstwirtschaft, Umwelt und Wasserwirtschaft, Sektion VII, Wien

Parker SP, Bowden WB, Flinn MB, Giles CD, Arndt KA, Beneś JP, Jent DG (2018) Effect of particle size and heterogeneity on sediment biofilm metabolism and nutrient uptake scaled using two approaches. Ecosphere 9:e02137. https://doi.org/10.1002/ecs2.2137

Pinheiro J, Bates D, DebRoy S, Sarkar D, Core Team R (2017) nlme: Linear and nonlinear mixed effects models. R package version 3.1131. https://CRAN.R-project.org/package=nlme>

R Core Team (2016) R: A language and environment for statistical computing. R Foundation for Statistical Computing, Vienna. https:// www.R-project.org/

Reice SR (1980) The role of substratum in benthic macroinvertebrate distribution in a woodland stream. Ecology 61:580-590

Root RB (1967) The niche exploitation pattern of the blue-gray gnatcatcher. Ecol Monogr 37:317-350. https://doi.org/10.2307/1942327

Scheder C, Waringer J (2002) Distribution patterns and habitat characterization of Simuliidae (Insecta: Diptera) in a low-order sandstone stream (Weidlingbach, Lower Austria). Limnologica 32:236-247. https://doi.org/10.1016/S0075-9511(02)80030-5

Simberloff D, Dayan T (1991) The guild concept and the structure of ecological communities. Ann Rev Ecol Syst 22:115-143. https:// doi.org/10.1146/annurev.es.22.110191.000555

Skuja A (2011) Microhabitat preference of caddisfly (Trichoptera) communities in medium-sized lowland stream in Latvia. Zoosymposia 5:425-433. https://doi.org/10.11646/zoosymposia.5.1.36

Statzner B, Elouard JM, Dejoux C (1987) Field experiments on the relationship between drift and benthic densities of aquatic insects in tropical streams (Ivory Coast). III. Trichoptera. Freshw Biol 17: 391-404. https://doi.org/10.1111/j.1365-2427.1987.tb01061.x

Stefan AW (1965) Zur Statik und Dynamik im Ökosystem der Fließgewässer und zu den Möglichkeiten ihrer Klassifizierung. In: Tüxen R (ed) Biosoziologie. Springer, Den Haag, pp 65-110

Stubbington R, Wood PJ, Reid I, Gunn J (2010) Benthic and hyporheic invertebrate community responses to seasonal flow recession in a groundwater-dominated stream. Ecohydrology 4:500-511. https:// doi.org/10.1002/eco.168

Stubbington R, Wood PJ, Reid I, Gunn J (2011) Spatial variability in the hyporheic zone refugium of temporary streams. Aquat Sci 73:499 511. https://doi.org/10.1046/j.1365-2427.2003.01093.x

Taira A, Tanida K (2013) Unusual behaviour and morphology of some Rhyacophila Pictet, 1834 caddisfly (Trichoptera: Rhyacophilidae) larvae reflect their ability to use the hyporheic zone. Aquat Insects 35:23-37. https://doi.org/10.1080/01650424.2014.949778

Tockner K, Waringer J (1997) Measuring drift during a receding flood: results from an Austrian mountain brook (Ritrodat-Lunz). Int Rev Hydrobiol 82:1-13. https://doi.org/10.1002/iroh.19970820102

Ulseth AJ, Bertuzzo E, Singer GA, Schelker J, Battin TJ (2018) Climateinduced changes in spring snowmelt impact ecosystem metabolism and carbon fluxes in an Alpine stream network. Ecosystems 21:373390. https://doi.org/10.1007/s10021-017-0155-7

Vannote RL, Minshall GW, Cummins KW, Sedell IR, Cushing CE (1980) The river continuum concept. Can J Fish Aquat Sci 37: $130-137$
Vieira Lanero R, González MA, Cobo F (1998) Larval description of Micrasema servatum (Navás, 1918) (Trichoptera, Brachycentridae). Graellsia 54:3-8. https://doi.org/10.3989/ graellsia.1998.v54.i0.336

Vitecek S, GrafW, Previšić A, Kučinić M, Oláh J, BálintM, Keresztes L, Pauls SU, Waringer J (2015) A hairy case: the evolution of filtering carnivorous Drusinae (Limnephilidae, Trichoptera). Mol Phylogen Evol 93:249-260. https://doi.org/10.1016/j.ympev.2015.07.019

Wallace ID (1990) A review of the Trichoptera of Great Britain. Res Surv Nat Conserv Ser 32:1-59

Ward JH (1963) Hierarchical grouping to optimise an objective function. J Am Stat Assoc 58:236-244

Waringer J (1987) Spatial distribution of Trichoptera larvae in the sediments of an Austrian mountain brook. Freshw Biol 18:469-482. https://doi.org/10.1111/j.1365-2427.1987.tb01332.x

Waringer J (1989) Resistance of a cased caddis larva to accidental entry into the drift: the contribution of active and passive elements. Freshw Biol 21:411-420. https://doi.org/10.1111/j.1365-2427. 1989.tb01373.x

Waringer J (1992) The drifting of invertebrates and particulate organic matter in an Austrian mountain brook. Freshw Biol 27:367-378. https://doi.org/10.1111/j.1365-2427.1992.tb00546.x

Waringer J, Graf W (2011) Atlas of Central European Trichoptera Larvae. Erik Mauch Publishers, Dinkelscherben

Waringer J, Malicky H (2019) Identification and morphology of a rhyacophilid caddisfly larva from Cyprus: Rhyacophila aphrodite Malicky 1975. Zootaxa 4623:563-570

Waringer J, Vitecek S, Martini J, Zittra C, Handschuh S, Vieira A, Kuhlmann H (2020) Hydraulic niche utilization by larvae of the three Drusinae clades (Insecta: Trichoptera). Biologia. https://doi. org/10.2478/s11756-020-00648-y

Welcomme RL, Winemiller KO, Cowx IG (2005) Fish environmental guilds as a tool for assessment of ecological condition of rivers. River Res Appl 21:1-20. https://doi.org/10.1002/rra.914

Whitbread K, Jansen J, Bishop P, Attal M (2015) Substrate, sediment, and slope controls on bedrock channel geometry in postglacial streams. J Geoph Res: Earth Surf 120:779-798. https://doi.org/10. 1002/2014JF003295

Zappa CJ, McGillis WR, Raymond PA, Edson JB, Hintsa EJ, Zemmelink HJ, Dacey JWH, Ho DT (2007) Environmental turbulent mixing controls on air-water gas exchange in marine and aquatic systems. Geoph Res Letters 34:L10601. https://doi.org/ 10.1029/2006GL028790

Zieritz A, Waringer J (2008) Distribution patterns and habitat characterization of aquatic Mollusca in the Weidlingbach near Vienna, Austria. Large Rivers 18:271-292. https://doi.org/10.1127/lr/18/ $2008 / 271$

Zwick P (1990) Emergence, maturation and upstream oviposition flights of Plecoptera from the Breitenbach, with notes on the adult phase as a possible control of stream insect populations. Hydrobiologia 194: 207-223

Zwick P, Zwick H (2010) Life history and development of Dictyogenus fontium (Plecoptera: Perlodidae) in two thermally contrasting streams at Lunz am See, Lower Austria. Denisia 29:459-475

Publisher's note Springer Nature remains neutral with regard to jurisdictional claims in published maps and institutional affiliations. 